Satriana Sitio ${ }^{1}$

\section{PENERAPAN STRATEGI PEMBELAJARAN AKTIF TIPE QUIZ TEAM UNTUK MENINGKATKAN HASIL BELAJAR IPA SISWA SEKOLAH DASAR}

\begin{abstract}
Abstrak
Penelitian ini dilatarbelakangi oleh rendahnya hasil belajar sains pada siswa kelas lima sekolah dasar negeri 004 Hangtuah Kabupaten Kampar. Salah satu solusi untuk mengatasi masalah ini adalah dengan menerapkan strategi kuis tipe active learning strategy. Tujuan penelitian untuk mendeskripsikan penerapan strategi pembelajaran tipe active quiz team untuk meningkatkan hasil belajar siklus air material sains dan kejadian alam pada siswa kelas lima SD Negeri 004 Hangtuah Kabupaten Kampar. Penelitian ini merupakan jenis Penelitian Tindakan Kelas (PTK) yang dilaksanakan dalam dua siklus. Setiap siklus terdiri dari satu pertemuan dan empat tahap, yaitu perencanaan, tindakan, pengamatan, dan refleksi. Waktu penelitian dilaksanakan mulai tanggal 07 Mei s / d 12 Mei 2018. Untuk mata pelajaran dalam penelitian ini adalah siswa kelas lima sekolah dasar negeri 004 Hangtuah kabupaten Kampar tahun ajaran sekolah 2017/2018 jumlah siswa 25 orang, terdiri dari 11 pria dan 14 wanita. Teknik pengumpulan data yang digunakan dalam penelitian ini adalah observasi, tes, dan dokumentasi. Setelah melakukan penelitian perhatikan peningkatan hasil belajar siswa dari tindakan sebelumnya, siklus pertama dan siklus kedua. Pada siswa penguasaan pre-action hanya mencapai 40,00\% atau 10 siswa yang tuntas, siswa yang lulus siklus pertama meningkat menjadi 17 orang atau kelengkapan hanya mencapai 68,00\%. Pada siklus II ternyata kelengkapan siswa pada 22 siswa atau persentase $88,00 \%$. Dengan demikian yaitu penerapan strategi pembelajaran tipe active quiz team untuk meningkatkan hasil belajar sains materi air siklus dan kejadian alam pada siswa kelas lima sekolah dasar negeri 004 Hangtuah Kabupaten Kampar.
\end{abstract}

Kata kunci: Strategi Pembelajaran Aktif Jenis Tim Kuis, Hasil Belajar Sains, Siklus Air dan Kejadian Alamiah.

Abstract

This research is motivated by the low learning result of science at the five year students of state elementary school 004 Hangtuah The Regency Of Kampar. One of solution to overcome this problem by implementation of active learning strategy type quiz team. The objective of study to describe implementation of active learning strategy type quiz team to increase learning result of science material water cycle and natural events at the five year students of state elementary school 004 Hangtuah the regency of Kampar. This research is a kind of Classroom Action Research (CAR) executed in two cycles. Every cycles consisted of bay one meeting and four phase, thas is planning, action, observation, and reflection. Research time executed to by start 07 May s/d 12 May 2018. For the subjects in this study is the five year students of state elementary school 004 Hangtuah the regency of Kampar 2017/2018 school year the number of students of 25 people, consisting of 11 men and 14 women. Data collection techniques used in this study is the observation, testing, and documentation. Having conducted research note an increase in student learning outcomes of prior actions, the first cycle and second cycle. In the pre-action mastery students only reached $40,00 \%$ or 10 students who completed, the students who pass the first cycle increased to 17 people or completeness only reached 68,00\%. In the second cycle turns completeness students at 22 students or the percentage of $88,00 \%$. Thereby that is the implementation of active learning strategy type quiz team to increase learning result of science the material water cycle and natural events at the five year students of state elementary school 004 Hangtuah the regency of Kampar.

Keywords : Active Learning Strategy Type Quiz, Team, Learning Result of Science, Water Cycle and Natural Events.

\footnotetext{
${ }^{1}$ Pendidikan Guru Sekolah Dasar Universitas Pahlawan Tuanku Tambusai Email : satriana994@gmail.com
} 


\section{PENDAHULUAN}

Pendidikan merupakan aspek yang sangat penting bagi jalannya pembangunan suatu bangsa. Dengan mutu pendidikan yang baik maka akan menciptakan sumber daya manusia yang bermutu tinggi. Ketersediaan sumber daya manusia yang bermutu harus dimulai sejak dini. Sumber daya manusia yang bermutu akan menciptakan pondasi ilmu yang kokoh. Pondasi yang kokoh akan memudahkan siswa dalam menguasai bidang ilmu yang lebih tinggi. Penciptaan pondasi ilmu pengetahuan dimulai dari pendidikan dasar.

Pendidikan dasar merupakan jenjang pendidikan yang melandasi pendidikan menengah, yang diselenggarakan dengan memberi keteladanan, membangun kemauan, dan mengembangkan kreativitas peserta didik dalam proses pembelajaran. Pendidikan dasar juga diselenggarakan dengan mengembangkan budaya membaca, menulis dan berhitung bagi siswa yang tercermin dalam beberapa disiplin ilmu yang diajarkan di Sekolah Dasar (SD). Salah satu bidang disiplin ilmu yang diajarkan adalah ilmu tentang alam atau yang lazim disebut Ilmu Pengetahuan Alam (IPA). Pendidikan IPA diarahkan untuk menemukan dan berbuat sehingga dapat membantu siswa untuk memperoleh pemahaman yang lebih mendalam tentang alam sekitar.

Materi pelajaran IPA harus dikuasai dengan baik oleh siswa. Dasar IPA yang baik akan membuat siswa lebih mudah mempelajari cabang IPA dimasa yang akan datang. Ilmu ini penting sekali dipelajari karena tanpa disadari kita selalu berhubungan dengan alam dalam kehidupan sehari-hari. Oleh karena itu, untuk mengajarkan IPA kepada siswa guru di sekolah harus mampu membangkitkan motivasi siswa-siswa untuk belajar, karena motivasi belajar yang tinggi akan berdampak baik bagi hasil belajar.

Melalui pembelajaran IPA, diharapkan peserta didik dapat membangun pengetahuannya melalui cara kerja ilmiah, bekerja sama dalam kelompok, belajar berinteraksi dan berkomunikasi, serta bersikap ilmiah. Pada dasarnya tujuan pembelajaran IPA di SD/MI agar peserta didik memiliki kemampuan sebagai berikut:

1) Memperoleh keyakinan terhadap kebesaran Tuhan Yang Maha Esa berdasarkan keberadaan, keindahan dan keteraturan alam ciptaan-Nya, 2) Menggembangkan pengetahuan dan pemahaman konsep-konsep IPA yang bermanfaat dan dapat diterapkan dalam kehidupan sehari-hari, 3) Mengembangkan rasa ingin tahu, sikap positif dan kesadaran tentang adanya hubungan yang saling mempengaruhi antara IPA, lingkungan, teknologi dan masyarakat, 4) Mengembangkan keterampilan proses untuk menyelidiki alam sekitar, memecahkan masalah dan membuat keputusan, 5) Meningkatkan kesadaran untuk berperan serta dalam memelihara, menjaga dan melestarikan lingkungan alam, 6) Meningkatkan kesadaran untuk menghargaan alam dan segala keteraturannya sebagai salah satu ciptaan tuhan, dan 7) Memperoleh bekal pengetahuan, konsep dan keterampilan IPA sebagai dasar untuk melanjutkan pendidikan ke SMP/MTs (Mulyasa, 2008: 111).

Berdasarkan penjelasan di atas, IPA perlu diberikan kepada semua peserta didik untuk membekali peserta didik dengan kemampuan berpikir logis, analitis an kreatif, serta kemampuan bekerjasama. Kompetensi tersebut diperlukan agar peserta didik dapat memiliki kemampuan memperoleh, mengelola, dan memanfaatkan informasi untuk bertahan hidup pada keadaan yang selalu berubah, tidak pasti dan kompetitif.

Seharusnya dalam pembelajaran IPA, siswa dapat menemukan dan memecahkan setiap permasalahan, memahami setiap jawaban, menyempurnakan jawaban, dan memiliki nilai dan hasil belajar yang ideal, yaitu hasil atau nilai yang diperoleh siswa 
mencapai KKM yang ditetapkan, yaitu 70. Kenyataannya mata pelajaran IPA yang diajarkan di kelas V SDN 004 Hangtuah Kabupaten Kampar belum terlaksana secara maksimal, dari nilai ulangan harian IPA tahun ajaran 2016/2017 terlihat dari 25 orang siswa hanya 10 siswa yang mencapai ketuntasan secara individu. Artinya dari $100 \%$ hanya $40 \%$ siswa yang mencapai KKM, sementara sisanya $60 \%$ tidak mencapai KKM yang telah ditetapkan, yaitu 70. Pada tabel 1 berikut dapat dilihat hasil ulangan harian IPA siswa kelas V SDN 004 Hangtuah Kabupaten Kampar, yaitu:

Tabel 1.1

Hasil Ulangan Harian IPA Materi Daur Air dan Peristiwa Alam Siswa Kelas V SDN 004 Hangtuah Kabupaten Kampar

Tahun Ajaran 2016/2017

\begin{tabular}{|c|l|c|c|c|}
\hline No & SISWA & JUMLAH & TUNTAS & TIDAK TUNTAS \\
\hline 1 & LAKI-LAKI & 9 & 5 & 4 \\
\hline 2 & PEREMPUAN & 16 & 5 & 11 \\
\hline \multicolumn{2}{|l|}{ TOTAL } & 25 & 10 & 15 \\
\hline \multicolumn{2}{|l|}{ PERSENTASE $(\%)$} & & $40 \%$ & $60 \%$ \\
\hline
\end{tabular}

Sumber: Guru Kelas V SDN 004 Hangtuah Kabupaten Kampar

Sementara itu berdasarkan pengamatan yang penulis lakukan pada tanggal 06 Februari 2018 ketika proses pembelajaran ditemukan permasalahan sebagai berikut: 1) adanya siswa yang kurang bekerjasama jika belajar dalam kelompok, 2) metode yang digunakan guru kurang bervariasi, guru masih terbiasa menggunakan metode ceramah, latihan, dan metode demonstrasi dalam pembelajaran IPA, 3) siswa merasa ragu untuk bertanya, ketika diminta untuk bertanya tentang materi yang kurang dipahaminya, 4) siswa kurang berminat untuk mengikuti pembelajaran, misalnya pada pembelajaran berlangsung, siswa banyak yang keluar masuk kelas, 5) pembelajaran lebih didominasi oleh guru, dalam proses pembelajaran guru lebih aktif, sementara siswa cenderung pasif, dan 6) strategi yang digunakan guru tidak efektif.

Berdasarkan permasalahan di atas, dipandang perlu dilakukan usaha perbaikan dalam proses pembelajaran. Usaha yang dapat dilakukan yaitu dengan menggunakan strategi pembelajaran yang sesuai. Salah satu yang dapat digunakan di dalam pembelajaran IPA dengan penerapan strategi pembelajaran aktif tipe Quiz Team.

Menurut Silbermen (2011:175) bahwa strategi pembelajaran aktif tipe Quiz Team merupakan strategi pembelajaran aktif yang berfungsi untuk menghidupkan suasana belajar, mengaktifkan siswa untuk bertanya maupun menjawab dan meningkatkan kemampuan tanggung jawab peserta didik terhadap apa yang mereka pelajari melalui cara yang menyenangkan dan tidak membosankan.

Selanjutnya Zaini (2010:57) menjelaskan bahwa diantara keunggulan strategi pembelajaran aktif tipe Quiz Team adalah: 1) untuk membantu siswa bersama-sama dengan timnya mempelajari materi dalam lembaran kerja, 2) mendiskusikan materi, dan saling memberikan arahan, 3) siswa aktif saling memberi pertanyaan dan jawaban, dan 4) siswa tidak hanya sekedar mendengarkan informasi dari guru, akan tetapi juga melihat apa yang dijelaskan oleh guru dan melakukan uji coba secara langsung, sehingga siswa tidak mudah lupa dan memahami materi tersebut, serta berdampak terhadap meningkatkatnya hasil belajar siswa.

Berdasarkan pendapat di atas, dengan strategi pembelajaran aktif tipe Quiz Team ini diharapkan siswa dapat menyelesaikan permasalahan IPA dengan baik, sehingga hasil belajar pun dapat ditingkatkan. Maka peneliti bermaksud untuk melakukan 
penelitian dengan judul: "Penerapan Strategi Pembelajaran Aktif Tipe Quiz Team Untuk Meningkatkan Hasil Belajar IPA Materi Daur Air dan Peristiwa Alam Pada Siswa Kelas V SDN 004 Hangtuah Kabupaten Kampar".

Berdasarkan latar belakang penelitian, maka dapat diidentifikasi masalah yang terjadi dalam pembelajaran, yaitu sebagai berikut :

1. Terdapat 10 orang siswa atau $40 \%$ yang suka mendominasi pembelajaran.

2. Metode yang digunakan guru kurang bervariasi, guru hanya menggunakan metode ceramah, tanpa divariasikan dengan metode tanya jawab, demonstrasi, latihan, dan metode penugasan.

3. Siswa merasa ragu untuk bertanya, ketika diminta untuk bertanya tentang materi yang kurang dipahaminya.

4. Siswa kurang berminat untuk mengikuti pembelajaran, terlihat saat proses pembelajaran berlangsung, siswa banyak yang keluar masuk kelas.

5. Pembelajaran lebih didominasi oleh guru, dalam proses pembelajaran guru lebih aktif, sementara siswa cenderung pasif.

6. Strategi yang digunakan oleh guru tidak efektif

Berdasarkan identifikasi masalah di atas, maka rumusan masalah penelitian ini secara umum adalah: apakah penerapan strategi pembelajaran aktif tipe quiz team dapat meningkatkan hasil belajar IPA materi daur air dan peristiwa alam pada Siswa Kelas V SDN 004 Hangtuah Kabupaten Kampar?

Berdasarkan rumusan masalah di atas, maka tujuan penelitian ini secara umum adalah untuk mendeskripsikan penerapan strategi pembelajaran aktif tipe quiz team dalam meningkatkan hasil belajar IPA materi daur air dan peristiwa alam pada Siswa Kelas V SDN 004 Hangtuah Kabupaten Kampar.

Sebagaimana yang telah dijelaskan pada kerangka pemikiran, maka hipotesis tindakan penelitian ini adalah dengan penerapan strategi pembelajaran aktif tipe quiz team, dapat meningkatkan hasil belajar IPA materi daur air dan peristiwa alam pada Siswa Kelas V SDN 004 Hangtuah Kabupaten Kampar.

\section{METODE PENELITIAN}

Tempat penelitian dilaksanakan di kelas V SDN 004 Hangtuah Kabupaten Kampar. Adapun waktu penelitian ini dilaksanakan pada bulan Mei tahun ajaran 2017/2018. Subjek dalam penelitian ini adalah siswa kelas V tahun ajaran 2017-2018 dengan jumlah siswa sebanyak 25 orang, yang terdiri dari 11 orang laki-laki dan 14 orang perempuan. Desain dasar penelitian ini adalah Penelitian Tindakan Kelas (PTK). Penelitian ini dilaksanakan dalam dua siklus dan tiap siklus dilakukan dalam dua kali pertemuan. Teknik pengumpulan data yang digunakan dalam penelitian ini adalah teknik tes, teknik observasi, dan teknik dokumentasi. Teknik analisis data yang digunakan dalam penelitian ini adalah teknik analisis kualitatif dan kuantitatif.

\section{HASIL DAN PEMBAHASAN} Deskripsi Pra Tindakan

Hasil belajar siswa pada mata pelajaran IPA materi daur air dan peristiwa alam pada siswa kelas V SDN 004 Hangtuah Kabupaten Kampar pada pratindakan dapat dilihat pada tabel 4.1. (data lengkapnya lampiran $17 \mathrm{hlm} .153$ )

Tabel 4.1

Hasil Belajar IPA Materi Daur Air dan Peristiwa Alam

Pada Siswa Kelas V SDN 004 Hangtuah

Kabupaten Kampar Pada Pratindakan 


\begin{tabular}{|c|c|c|c|}
\hline \multirow{2}{*}{ No } & \multirow{2}{*}{ Interval (\%) } & $\mathrm{N}$ & Pratindakan \\
\cline { 2 - 4 } & & 1 & $4,00 \%$ \\
\hline 1 & $85-100$ (Amat Baik) & 1 & $4,00 \%$ \\
\hline 2 & $71-84$ (Baik) & 8 & $32,00 \%$ \\
\hline 3 & $65-70$ (Cukup) & 15 & $60,00 \%$ \\
\hline 4 & $<65$ (Kurang) & 25 & $100.00 \%$ \\
\hline \multirow{2yy}{*}{ JUMLAH SISWA } & \multicolumn{3}{|c|}{60.40} \\
\hline RATA-RATA & $\mathbf{1 0}$ & $40,00 \%$ \\
\hline \multicolumn{2}{|r|}{ KATEGORI } & $\mathbf{1 5}$ & $60,00 \%$ \\
\hline \multicolumn{2}{|c|}{ JUMLAH YHANG TIDAK TUNTAS }
\end{tabular}

Berdasarkan tabel 4.1, diketahui bahwa persentase ketuntasan siswa pada pratindakan hanya mencapai persentase $40,00 \%$ atau 10 orang siswa yang tuntas. Persentase tidak tuntas sebesar $60,00 \%$ atau 15 orang siswa yang tidak tuntas. Kemudian rata-rata pratindakan siswa mencapai 60,40 dengan kategori kurang. Artinya keberhasilan siswa belum mencapai 75\%. Untuk itu, perlu tindakan untuk meningkatan hasil belajar IPA materi daur air dan peristiwa alam melalui penelitian tindakan kelas dengan penerapan strategi pembelajaran aktif tipe quiz team.

\section{Deskripsi Hasil Penelitian Siklus I}

\section{Hasil Pengamatan Aktivitas Guru Siklus I}

Berdasarkan hasil pengamatan siklus I, diketahui bahwa pada kegiatan awal belum terlaksana dengan baik, diantaranya apersepsi dan motivasi yang guru berikan masih kurang respon dari siswa. Sedangkan tujuan pembelajaran telah disampaikan guru dengan baik dan benar. Pada kegiaan inti masih banyak kekurangan, seperti materi pelajaran kurang diperjelas dengan contoh, pembagian tim belum tertib, masih kurangnya pengawasan guru ketika kuis berlangsung, waktu belum ditetapkan ketika kuis berlangsung, sehingga kegiatan tersebut berlangsung lama, dan suasana kelas ketika kuis berlangsung masih belum tertib. Pada kegiatan akhir guru tidak memberikan kesempatan bertanya. Berdasarkan hasil pengamatan pertemuan 2 siklus I, diketahui bahwa pada kegiatan awal mulai membaik dari pertemuan sebelumnya, diantaranya apersepsi dan motivasi yang guru berikan mulai mendapatkan respon dari siswa, tetapi perlu ditingkatkan lagi. Dan tujuan pembelajaran telah disampaikan guru dengan baik dan benar. Pada kegiaan inti tidak jauh berbeda dengan pertemuan 1 yaitu: materi pelajaran kurang diperjelas dengan contoh, kurangnya bimbingan guru ketika pembagian tim sehingga masih belum tertib, masih kurangnya pengawasan guru ketika kuis berlangsung, waktu kuis sudah ditetapkan, namun suasana kelas ketika kuis berlangsung masih belum tertib. Pada kegiatan akhir guru telah memberikan kesempatan bertanya, namun hanya siswa tertentu saja.

\section{Hasil Observasi Aktivitas Siswa Pada Siklus I}

Aktivitas siswa dalam proses pembelajaran IPA materi daur air dan peristiwa alam dengan penerapan strategi pembelajaran aktif tipe quiz team di siklus I dilaksanakan dan dinilai oleh pengamat berdasarkan lembar aktivitas siswa (lampiran $15 \mathrm{hlm}$. 141). Berdasarkan hasil pengamatan pertemuan 1 siklus I terhadap aktivitas siswa, diketahui bahwa pada kegiatan awal belum terlaksana dengan baik, diantaranya tingkat respon siswa menjawab pertanyaan apersepsi dan motivasi yang guru berikan masih sangat rendah, kurangnya antusias siswa untuk mendengarkan 
tujuan pembelajaran yang disampaikan guru. Pada kegiaan inti banyak siswa yang tidak memperhatikan dan mendengarkan guru menjelaskan materi pelajaran, masih suka bermain ketika membentuk tim, sehingga kondisi kelas kurang tertib, terlalu lama ketika melaksanakan kegiatan kuis, dan siswa masih belum dapat menciptakan suasana kelas yang tertib. Pada kegiatan akhir siswa kurang antusias untuk bertanya.

Hasil pengamatan pada pertemuan 2 siklus I terhadap aktivitas siswa tidak jauh berbeda dengan pertemuan 1, yaitu pada kegiatan awal siswa masih kurang berani untuk menjawab pertanyaan apersepsi dan motivasi yang guru berikan, namun mulai antusias mendengarkan tujuan pembelajaran yang disampaikan guru. Pada kegiatan inti siswa sudah mulai memperhatikan dan mendengarkan guru menjelaskan materi pelajaran, namun masih belum fokus, yaitu masih melihat kanan kiri. Masih belum tertib dan bermain ketika membentuk tim. Masih terlalu lama ketika melaksanakan kegiatan kuis, dan siswa masih belum dapat menciptakan suasana kelas yang tertib selama kuis berlangsung. Pada kegiatan akhir siswa yang mulai berani untuk bertanya hanya beberapa orang saja.

\section{Hasil Belajar Tes Siklus I}

Hasil tes siswa pada siklus I dapat dilihat pada tabel 4.2. Data lebih lengkapnya dapat dilihat pada tabel 4.2 (Lampiran $17 \mathrm{hlm}$. 154).

Tabel 4.2

Hasil Belajar IPA Materi Daur Air dan Peristiwa Alam

Pada Siswa Kelas V SDN 004 Hangtuah

Kabupaten Kampar Pada Siklus I

\begin{tabular}{|c|c|c|c|}
\hline \multirow{2}{*}{ No } & \multirow{2}{*}{ Interval (\%) } & $\mathrm{N}$ & Siklus I \\
\cline { 2 - 4 } & & 3 & $12,00 \%$ \\
\hline 1 & $85-100$ (Amat Baik) & 12 & $48,00 \%$ \\
\hline 2 & $71-84$ (Baik) & 7 & $28,00 \%$ \\
\hline 3 & $65-70$ (Cukup) & 3 & $12,00 \%$ \\
\hline 4 & $<65$ (Kurang) & 25 & $100.00 \%$ \\
\hline & JUMLAH SISWA & \multicolumn{2}{|c|}{70.77} \\
\hline \multicolumn{2}{|c|}{ RATA-RATA } & $\mathbf{1 7}$ & $68,00 \%$ \\
\hline & KATEGORI & $\mathbf{8}$ & $32,00 \%$ \\
\hline \multicolumn{2}{|c|}{ JUMLAH YANG TUNTAS } \\
\hline
\end{tabular}

Berdasarkan tabel 4.2, diketahui bahwa persentase ketuntasan siswa pada siklus I mencapai persentase $68,00 \%$ atau 17 orang siswa yang tuntas. Persentase tidak tuntas sebesar $32,00 \%$ atau 8 orang siswa yang tidak tuntas. Kemudian rata-rata hasil belajar siswa pada siklus I mencapai 70,77 dengan kategori cukup. Walaupun hasil belajar siswa tergolong cukup, namun keberhasilan siswa belum mencapai $75 \%$. Untuk itu, perlu tindakan siklus berikutnya untuk meningkatan hasil belajar siswa tersebut, yaitu dengan penerapan strategi pembelajaran aktif tipe quiz team pada siklus II.

\section{Refleksi Siklus I}

Berdasarkan hasil tes pada siklus I, diketahui bahwa jumlah siswa yang tuntas berjumlah 17 orang siswa atau $68,00 \%$, sedangkan yang tidak tuntas berjumlah 8 orang siswa atau $32,00 \%$. Adapun penyebab siswa yang tidak tuntas adalah tingkat respon siswa menjawab pertanyaan apersepsi dan motivasi yang guru berikan masih sangat rendah, kurangnya antusias siswa untuk mendengarkan tujuan pembelajaran yang disampaikan guru. Banyak siswa yang tidak memperhatikan dan mendengarkan 
guru menjelaskan materi pelajaran, masih suka bermain ketika membentuk tim, terlalu lama ketika melaksanakan kuis, dan masih belum dapat menciptakan suasana kelas yang tertib. Pada kegiatan akhir siswa kurang antusias untuk bertanya.

Kemudian pelaksanaan strategi pembelajaran quiz team pada siklus I masih banyak kekurangan, seperti materi pelajaran kurang diperjelas dengan contoh, pembagian tim belum tertib, masih kurangnya pengawasan guru ketika kuis berlangsung, waktu belum ditetapkan ketika kuis berlangsung, sehingga kegiatan tersebut berlangsung lama, dan suasana kelas ketika kuis berlangsung masih belum tertib. Pada kegiatan akhir guru tidak memberikan kesempatan bertanya.

Untuk pertemuan selanjutnya sebaiknya guru harus mempersiapkan pertanyaan apersepsi dan motivasi yang menimbulkan rasa ingin tahu siswa, agar respon dari siswa meningkat. Menyampaikan tujuan pembelajaran dengan baik dan benar. Pada kegiatan inti lebih memperjelas materi pelajaran dengan contoh, membagi tim dengan tertib, menetapkan waktu ketika pelaksanaan kuis, agar kegiatan tersebut tidak berlangsung lama. Pada kegiatan akhir sebagiknya guru memberikan kesempatan bertanya. Berdasarkan refleksi siklus I, maka penelitian ini dilanjutkan ke siklus II.

\section{Deskripsi Hasil Penelitian Siklus II}

\section{Hasil Pengamatan Aktivitas Guru Siklus II}

Aktivitas guru dalam proses pembelajaran IPA materi daur air dan peristiwa alam dengan penerapan strategi pembelajaran aktif tipe quiz team di siklus II dilaksanakan dan dinilai oleh pengamat berdasarkan lembar penilaian aktivitas guru (lampiran $14 \mathrm{hlm}$. 135). Berdasarkan hasil pengamatan, diketahui bahwa pelaksanaan pembelajaran pertemuan 1 siklus II telah terlaksana dengan baik. Pada kegiatan awal mulai membaik dari pertemuan sebelumnya, diantaranya apersepsi dan motivasi yang guru berikan banyak yang ingin memberikan tanggapan, dan guru memberikan kesempatan kepada seluruh siswa yang mengacungkan tangan untuk meresponnya. Dan tujuan pembelajaran telah disampaikan guru secara keseluruhan dengan baik dan benar. Pada kegiaan inti materi pelajaran telah disampaikan dengan baik dan diperjelas dengan contoh, pembagian tim telah terlaksana dengan tertib, waktu telah ditetapkan ketika kuis berlangsung, sehingga siswa dan kelompok yang melebihi waktu yang ditetapkan hampir tidak ada. dan Suasana kelas selama kegiatan kuis sudah mulai lebih tertib. Pada kegiatan akhir guru telah memberikan kesempatan bertanya bagi siswa yang menunjuk tangan.

Berdasarkan hasil pengamatan pertemuan 2 siklus II, diketahui bahwa pelaksanaan pembelajaran telah terlaksana dengan sangat baik. Pada kegiatan awal terlaksana dengan sangat baik, seperti apersepsi dan motivasi yang guru berikan banyak yang ingin memberikan tanggapan, dan guru memberikan kesempatan kepada seluruh siswa yang mengacungkan tangan untuk meresponnya. Dan tujuan pembelajaran telah disampaikan guru secara keseluruhan dengan baik dan benar. Pada kegiaan inti materi pelajaran telah disampaikan dengan baik dan diperjelas dengan contoh, pembagian tim telah terlaksana dengan sangat tertib, waktu telah ditetapkan ketika kuis berlangsung, sehingga siswa dan kelompok yang melebihi waktu yang ditetapkan pada pertemuan 2 siklus II ini sudah tidak ada. Dan suasana kelas selama kegiatan kuis berlangsung sangat tertib. Pada kegiatan akhir guru telah memberikan kesempatan bertanya bagi siswa yang menunjuk tangan.

\section{Hasil Observasi Aktivitas Siswa Pada Siklus II}


Aktivitas siswa dalam proses pembelajaran IPA materi daur air dan peristiwa alam dengan penerapan strategi pembelajaran aktif tipe quiz team di siklus II dilaksanakan dan dinilai oleh pengamat berdasarkan lembar aktivitas siswa (lampiran $16 \mathrm{hlm}$. 147). Berdasarkan hasil pengamatan pertemuan 1 siklus II terhadap aktivitas siswa, diketahui bahwa pada kegiatan awal siswa mulai berani untuk menjawab pertanyaan apersepsi dan motivasi yang guru berikan, dan antusias mendengarkan tujuan pembelajaran yang disampaikan guru. Pada kegiatan inti siswa telah memperhatikan dan mendengarkan guru menjelaskan materi pelajaran, dan membentuk tim dengan tertib. Kegiatan kuis mulai dilaksanakan dengan tepat waktu, dan siswa mulai dapat menciptakan suasana kelas yang tertib selama kuis berlangsung. Pada kegiatan akhir siswa telah membuat kesimpulan pelajaran, dan mengajukan pertanyaan, serta memperhatikan dan mendengarkan guru memberikan tidak lanjut.

Hasil pengamatan pada pertemuan 2 siklus II, diketahui bahwa pada kegiatan awal siswa yang berani untuk menjawab pertanyaan apersepsi dan motivasi yang guru berikan meningkat sangat signifikan, dan sangat antusias mendengarkan tujuan pembelajaran yang disampaikan guru. Pada kegiatan inti siswa telah memperhatikan dan mendengarkan guru menjelaskan materi pelajaran dengan sangat fokus, dan membentuk tim dengan sangat tertib. Kegiatan kuis dilaksanakan dengan tepat waktu, dan suasana kelas selama kuis berlangsung sangat tertib. Pada kegiatan akhir siswa telah membuat kesimpulan pelajaran, dan mengajukan pertanyaan, serta memperhatikan dan mendengarkan guru memberikan tidak lanjut.

\section{Hasil Belajar Tes Siklus II}

Hasil tes siswa pada siklus II dapat dilihat pada tabel 4.3. Data lebih lengkapnya dapat dilihat pada 4.3 (Lampiran $17 \mathrm{hlm} .155$ ).

Tabel 4.3

Hasil Belajar IPA Materi Daur Air dan Peristiwa Alam

Pada Siswa Kelas V SDN 004 Hangtuah

Kabupaten Kampar Pada Siklus II

\begin{tabular}{|c|c|c|c|}
\hline \multirow{2}{*}{ No } & \multirow{2}{*}{ Interval (\%) } & $\mathrm{N}$ & Siklus II \\
\cline { 2 - 4 } & & 4 & $16,00 \%$ \\
\hline 1 & $85-100$ (Amat Baik) & 16 & $64,00 \%$ \\
\hline 2 & $71-84$ (Baik) & 2 & $12,00 \%$ \\
\hline 3 & $65-70$ (Cukup) & 25 & $8,00 \%$ \\
\hline 4 & $<65$ (Kurang) & \multicolumn{2}{|c|}{76.66} \\
\hline & JUMLAH SISWA & $\mathbf{2 2}$ & $800.00 \%$ \\
\hline \multicolumn{2}{|c|}{$\mathbf{3}$} & $12,00 \%$ \\
\hline & RATA-RATA &
\end{tabular}

Berdasarkan tabel 4.3, diketahui bahwa persentase ketuntasan siswa pada siklus II mencapai persentase $88,00 \%$ atau 22 orang siswa yang tuntas. Persentase tidak tuntas sebesar $12,00 \%$ atau 3 orang siswa yang tidak tuntas. Kemudian rata-rata hasil belajar siswa pada siklus II mencapai 76,66 dengan kategori baik. Artinya hasil belajar siswa telah melebihi $75 \%$. Untuk itu, penelitian ini hanya cukup dilaksanakan sebanyak 2 siklus.

\section{Refleksi Siklus II}


Pada siklus II hasil belajar IPA materi tumbuhan daur air dan peristiwa alam dengan penerapan penerapan strategi pembelajaran quiz team telah melebihi indikator keberhasilan sebesar $75 \%$. Adapun jumlah siswa yang tuntas pada siklus II mencapai 22 orang siswa atau dengan persentase sebesar $88,00 \%$, dan siswa yang tidak tuntas hanya berjumlah 3 orang siswa dengan persentase $12 \%$ berinisial AZH, ES dan V. Adapun penyebabnya 3 orang siswa tersebut adalah memang termasuk siswa yang lambat menguasai materi pelajaran, dan malu bertanya apabila tidak mengerti tentang pelajaran. Sedangkan penyebab dari langkah-langkah strategi pembelajaran quiz team adalah guru belum sepenuhnya mampu menciptakan suasana kelas yang tertib dan kurangnya pengawasan guru ketika pelaksanaan kuis tim, sehingga siswa yang tidak tuntas lebih banyak bermain, dan kurangnya kerja sama siswa dalam tim mereka.

Berhubungan penelitian ini hanya dilaksanakan sebanyak 2 siklus, maka tindak lanjut permasalahan yang terjadi guru lebih banyak memberikan latihan dan tugas rumah, dan meminta wali murid tersebut untuk memantaunya di rumah, serta mengulang-ulang materi di rumah.

\section{Perbandingan Hasil Tindakan Antar Siklus}

Sebagaimana diketahui bahwa pada siklus I hasil belajar siswa telah menunjukkan peningkatan dari sebelum tindakan, begitu juga pada siklus II meningkat dari siklus I. Peningkatan hasil belajar siswa dari sebelum tindakan hingga siklus II dapat dilihat pada tabel 4.4.

Tabel 4.4

Peningkatan Ketuntasan Hasil Belajar Siswa Dari Sebelum Tindakan, Siklus I dan Siklus II

\begin{tabular}{|c|c|c|c|}
\hline Keterangan & Pra Tindakan & Siklus I & Siklus II \\
\hline Rata-Rata & 60,40 & 70,77 & 76,66 \\
\hline Persentase Ketuntasan & $10(40,00 \%)$ & $17(68,00 \%)$ & $22(88,00 \%)$ \\
\hline
\end{tabular}

Berdasarkan tabel 4.4, diketahui pada sebelum tindakan siswa yang tuntas hanya 10 orang siswa atau $40 \%$ dengan rata-rata 60,40. Sedangkan pada siklus I meningkat menjadi 17 orang siswa atau 68,00\% dengan rata-rata 70,77. Pada siklus II diketahi bahwa siswa yang tuntas mencapai 22 orang siswa atau dengan persentase $88,00 \%$, dan rata-rata hasil belajar siswa pada siklus II adalah 76,66. Jumlah siswa yang tuntas meningkat, yaitu dari 10 orang $(40,00 \%)$ menjadi 22 orang $(88,00 \%)$ pada siklus II.

\section{PEMBAHASAN}

Siklus I hasil belajar siswa telah menunjukkan peningkatan dari sebelum tindakan siswa yang tuntas secara keseluruhan adalah 10 orang siswa atau dengan persentase $40,00 \%$. Hal ini disebabkan pada sebelum tindakan proses pembelajaran yang dilaksanakan guru belum mampu meningkatkan hasil belajar siswa, guru masih cenderung menggunakan metode ceramah dan tanya jawab. Sehingga belum mampu membuat siswa aktif, baik bertanya, maupun mengeluarkan pendapat. Untuk mengatasi kelemahan yang terjadi pada pra tindakan, maka perlu strategi pembelajaran yang dapat meningkatkan hasil belajar siswa, membuat siswa aktif bertanya, dan aktif belajar secara mandiri maupun kelompok. Salah satunya adalah dengan strategi pembelajaran aktif tipe quiz team. Pada siklus I siswa yang tuntas secara keseluruhan meningkat 
menjadi 17 orang siswa atau dengan persentase $68,00 \%$. Sedangkan yang tidak tuntas terdapat 8 orang siswa atau dengan persentase $32,00 \%$. Dengan demikian pada siklus II keberhasilan siswa belum mencapai $75 \%$. Masih banyak siswa yang tidak tuntas disebabkan oleh siswa masih kurang berani untuk menjawab pertanyaan guru, kurang antusias mendengarkan guru menyampaikan materi pelajaran, masih suka bermain-main ketika membentuk tim, dan kurangnya kerja sama tim ketika kuis berlangsung.

Pada siklus II siswa yang tuntas secara keseluruhan adalah 22 orang siswa atau dengan persentase $88,00 \%$. Hal ini disebabkan guru dan siswa sudah terbiasa dengan penerapan strategi pembelajaran aktif tipe quiz team, siswa lebih mudah memahami materi pelajaran. Yang tidak tuntas berjumlah 3 orang siswa, hal ini disebabkan siswa tersebut memang termasuk siswa yang lambat menguasai materi pelajaran, dan malu bertanya apabila tidak mengerti tentang pelajaran. Berdasarkan permasalahan yang terjadi guru lebih banyak memberikan latihan dan tugas rumah, dan meminta wali murid tersebut untuk memantaunya di rumah, serta mengulang-ulang materi di rumah.

Ismail (2011:86) menjelaskan bahwa strategi pembelajaran aktif tipe quiz team dapat mengaktifkan siswa baik secara individu dan kelompok. Apabila siswa telah aktif baik secara individu dan kelompok, diperkirakan dapat meningkatkan hasil belajar siswa. Pembelajaran menjadi lebih santai bukan menakutkan, dan pmbelajaran lebih menyenangkan bukan membosankan.

\section{SIMPULAN}

Berdasarkan hasil penelitian yang telah dipaparkan di atas, maka dapat disimpulkan bahwa pada sebelum tindakan siswa yang tuntas hanya 10 orang siswa atau $40,00 \%$. Sedangkan pada siklus I meningkat menjadi 17 orang siswa atau 68,00\%. Pada siklus II meningkat lagi hingga mencapai 22 orang siswa atau dengan persentase $88,00 \%$. Dengan demikian keberhasilan siswa pada siklus II telah melebihi $75 \%$. 


\section{DAFTAR PUSTAKA}

Arikunto, S. 2007. Penelitian Tindakan Kelas. Jakarta: Rineka Cipta.

1998. Prosedur Penelitian (Suatu Pendekatan Praktek. Jakarta: Rineka Cipta.

Aunurrahman. 2009. Belajar dan Pembelajaran. Bandung: Alfabeta.

Bahrissalim \& Haris, 2011. Modul Strategi dan Model-Model PAIKEM. Jakarta: Zanafa.

Dimyati dan Munjiono. 2000. Belajar dan Pembelajaran. Jakarta: Rineka Cipta.

Emzir. 2010. Metodologi Penelitian Pendidikan Kuantitatif \& Kualitatif. Jakarta: Rajawali Pers.

Ginting, A. 2008. Esensi Praktis Belajar dan Pembelajaran. Bandung: Humaniro.

Hamid, Moh. S. 2011. Metode Edu Tainment (Menjadikan Siswa Kreatif dan Nyaman di Kelas). Yogyakarta: Diva Press (Anggota IKAPI).

Ismail. 2011. Strategi Pembelajaran Berbasis PAIKEM. Semarang: RaSAIL Media Group.

Muijs, D \& Reynolds, D. 2008. Effective Teaching Teori dan Aplikasi. Yogyakarta: Pustaka Pelajar.

Mulyasa, 2008. Kurikulum Tingkat Satuan Pendidikan (KTSP). Bandung: PT. Remaja Rosdakarya.

Samatowa, U. 2011. Bagaimana Membelajarkan IPA di Sekolah Dasar, Jakarta: Depdiknas

Sardiman. 2004. Interaksi dan Motivasi Belajar Mengajar, Jakarta: PT. Raja Grafindo Persada

Silbermen, M.L. 2011. Active Learning 101 Strategi Pembelajaran Aktif, Yogyakarta: Nusamedia

Sudjana, N. 2009. Penilaian Hasil Belajar Mengajar. Bandung: Rosda Karya.

Suprijono, A. 2009. Cooperative Learning: Teori dan Aplikasi PAIKEM. Yogyakarta: Pustaka Pelajar.

Sutikno, S. 2009. Belajar dan Pembelajaran. Bandung: Prospect.

Syah, M. 2008. Psikologi Belajar. Jakarta: PT.Raja Grafindo Persada. 
Trianto. 2008. Mendesain Pembelajaran Kontekstual (Contextual Teaching and Learning) di Kelas. Jakarta: Cerdas Pustaka Publisher.

Trianto. 2007. Model Pembelajaran Terpadu dalam Teori dan Praktek, Jakarta: Publisher.

Tu'u, T. 2004. Peran Disiplin Pada Perilaku dan Prestasi Siswa. Jakarta: Grasindo

Yustisia, T.P. 2008. Panduan Lengkap KTSP. Yokyakarta: Pustaka Yustisia.

Wardani, dkk. 2006. Penelitian Tindakan Kelas. Jakarta: Universitas Terbuka.

Zaini, H. 2010. Strategi Pembelajaran Aktif. Yogyakarta: CTSD. 